\title{
Canonical Babbling in Korean-Acquiring Infants at 4-9 Months of Age
}

\author{
Seunghee $\mathrm{Ha}^{\mathrm{a}}$, D. Kimbrough Oller \\ ${ }^{a}$ Division of Speech Pathology and Audiology, Audiology and Speech Pathology Research Institute, Hallym University, Chuncheon, Korea \\ ${ }^{b}$ Department of Communication Sciences and Disorders, University of Memphis, Memphis, TN, USA
}

\author{
Correspondence: Seunghee $\mathrm{Ha}, \mathrm{PhD}$ \\ Division of Speech Pathology and Audiology, \\ Audiology and Speech Pathology Research \\ Institute, Hallym University, 1 Hallymdaehak-gil, \\ Chuncheon 24252, Korea \\ Tel: $+82-33-248-2215$ \\ Fax: +82-33-256-3420 \\ E-mail: shha@hallym.ac.kr
}

Received: January 5, 2019

Revised: February 3, 2019

Accepted: February 18, 2019

This research has been supported by the National Research Foundation of Korea Grant funded by the Korean Government (No. NRF-2016S1A2911363) and Hallym University Research Fund (No. HRF201812-013).
Objectives: Canonical babbling is a key feature of vocal development in the first year. This study aimed to examine changes in canonical babbling in Korean-acquiring infants from 4 to 9 months of age based on vocal samples obtained through all-day recordings in naturalistic environments. Methods: Language ENvironment Analysis (LENA) all-day home recordings were obtained from 13 infants aged 4-6 months and 13 infants aged 7-9 months. Twenty 5-minute segments with the highest child vocalization rate were extracted from each infant's LENA recording. The coders, who received intensive coding training, determined syllable types (canonical, non-canonical, glide, or glottal syllables) while listening to the selected recordings. The effects of age and gender were determined on the number of each syllable type and canonical babbling ratios (CBR). Results: The results indicated that infants aged 7-9 months produced significantly more canonical syllables and showed higher CBR than infants aged 4-6 months. Eight 7 to 9-month-old infants had entered canonical babbling stage. Boys produced significantly more canonical syllables and showed higher CBR than girls in this study. Conclusion: This study is the first effort to evaluate canonical babbling in Korean-acquiring infants and examine vocal development through a representative sampling of vocalizations in natural environments through day-long recordings.

Keywords: Canonical babbling, Language ENvironment Analysis, 4 to 9 months, Koreanacquiring children
생후 1년 동안 순차적으로 발달해 나가는 아동의 발성은 이후 말-언어 발달의 기초를 이룬다. 아동의 발성은 조음기관의 움직임 없이 성대의 짧은 진동으로 만들어지는 준 모음(quasi-vowels)에서 부터 시작하여 점진적으로 성대의 정상적인 진동과 완전한 공명이 가미되면서 완전한 모음으로 발전해 나간다. 또한 입술과 혀의 수의 적인 움직임 조절이 가능해지면서 자음 같은 소리(closant)가 포함 된 경계선 옹알이(marginal babbling)가 산출된다. 경계선 옹알이 의 주요한 청지각적 특징인 자음 같은 소리와 모음 사이의 긴 전이 구간(transition)은 아동이 성장함에 따라 조음기관의 폐쇄와 개방 의 움직임이 빨라져 점차 짧아진다. 자음과 모음 같은 소리가 음향 학적으로 보다 뚜렷해지고, 전이구간이 짧아지면서 음절성 옹알이 (canonical babbling)를 산출하게 된다(Lee, Jhang, Relyea, Chen, \& Oller, 2018). 자음과 모음이 적어도 한 개씩 포함되는 음절성 옹 알이(canonical babbling)는 이후 아동이 산출하는 낱말의 기본적 인 음성적 단위로서 기능을 한다. 따라서 음절성 옹알이의 산출은 아동이 의미 있는 낱말을 표현하는 것을 학습하기 전에 먼저 갖추 어야 하는 능력이다. 음절성 옹알이의 출현은 생후 1 년 동안 점진적 으로 습득해가는 말산출 능력에 있어서 가장 중요한 발달을 의미 하기 때문에 음절성 옹알이의 출현 여부와 시기를 아동에게서 확 인하는 것은 임상적으로 중요하다.

Oller와 그의 동료들은 아동이 산출한 전체 발성을 음절 단위로 구분하여 분석한 후 음절성 옹알이가 차지하는 비율이 .15 이상일 경우, 음절성 옹알이를 어느 정도 일관성있게 산출할 수 있음을 의 미하여 아동이 음절성 옹알이 단계에 진입한 것으로 판단하였다 (Lynch et al., 1995; Oller, Eilers, Steffens, Lynch, \& Urbano, 1994). 음절성 옹알이 단계에 대한 이러한 기준을 사용할 경우 많은 수의 
일반아동이 5-6개월경에, 늦어도 10개월 이전에는 음절성 옹알이 단계에 진입하는 것으로 보고된다(Lee et al., 2018). 반면에 청각장 애, 구개열, 다운증후군과 같은 선천적 문제를 가지고 태어난 아동 들은 음절성 옹알이의 산출이 지연되는 것으로 보고된다(Chapman, Hardin-Jones, Schulte, \& Halter, 2001; Cobo-Lewis, Oller, Lynch, \& Levine, 1996; Ertmer, Young, \& Nathani, 2007; Iyer \& Ertmer, 2014; Nathani, Ertmer, \& Stark, 2006; Oller, Eilers, Bull, \& Carney, 1985). 한 예로 Chapman 등(2001)은 생후 9개월의 구개열 아동과 일반아동을 대상으로 .15의 기준을 바탕으로 음절성 옹알 이 단계에 진입한 아동의 현황을 살펴보았다. 연구결과, 일반아동 의 $93 \%$ 가 음절성 옹알이 단계에 도달하였지만 구개열 아동은 $57 \%$ 만이 .15 이상의 음절성 옹알이 비율을 보여 많은 수의 구개열 아동 이 음절성 옹알이를 늦게 산출하는 것으로 나타났다. 또한 구개열 아동과 일반아동을 대상으로 진행된 종단연구에서는 일반아동의 경우 9 개월과 13 개월에 성문/인두음, 활음을 제외한 진자음(true consonants)으로만 구성된 음절성 옹알이의 비율이 각각 21 개월의 부모 어휘 체크리스트에서 나타난 어휘 크기와 자발화에서 나타난 자음목록 및 파열음 비율과 유의한 상관관계가 있음이 밝혀졌다 (Chapman, Hardin-Jones, \& Halter, 2003). 이러한 연구는 음절성 옹알이의 양, 구조, 시작 시기와 관련된 정보가 이후 자음목록과 어 휘발달 현황과 문제를 예측할 수 있는 근거자료로서 임상적으로 중 요함을 제안하고 있다.

말-언어발달 과정에 있어서 음절성 옹알이의 중요성으로 인해 현 재까지 많은 연구가 진행되어 왔다. 하지만 음절성 옹알이를 살펴 본 대부분의 연구가 부모 보고나 실험실 상황에서 수집된 아동의 짧은 발성 자료를 토대로 이루어져 자연스런 환경에서의 아동의 발 성 발달 수준을 관찰하는데 제한적이고 아동의 발성에 대한 대표 성이 떨어진다(Lee et al., 2018; Oller, Levine, Cobo-Lewis, Eilers, \& Pearson, 1998). 이러한 연구방법상의 제한점은 최근 미국에서 아 동 언어발달에 긍정적인 언어환경을 확인하고 언어발달을 촉진하 기 위해 개발된 언어환경 분석기(Language ENvironmental Analysis, LENA)로 인해 극복될 수 있게 되었다. 아동의 옷 주머니에 12 시간 이상 연속해서 녹음할 수 있는 LENA 녹음기를 넣어 자연스 런 환경에서 아동의 발성을 풍부하게 수집할 수 있게 되었다. 따라 서 최근 국외 초기 발성연구에서는 LENA를 이용하여 아동의 가정 에서 하루 동안 수집한 자료를 토대로 발성의 양과 구조를 살펴보 고 있다(Gikerson et al., 2017; Lee et al., 2018; Oller et al., 2010). 한 예로 Lee 등(2018)은 LENA를 이용하여 생후 6개월과 11개월의 영 어권과 중국어권 아동을 대상으로 전체 발성 중 음절성 옹알이의 비율을 살펴보았다. 연구결과, 음절성 옹알이의 비율이 아동의 월
령뿐만 아니라 언어 및 문화 환경, 상호작용 환경에 복합적으로 영 향을 받으면서 달라졌다. 선행연구의 이러한 결과는 언어이전기 발 성은 언어의 보편적인 특성뿐만 아니라 아동에게 노출된 언어에 국 한된 고유한 특성이 나타날 수 있고, 아동을 양육하는 문화와상호 작용 방식에 따라 복합적으로 달라질 수 있음을 제안하고 있다.

현재 초기 발성에 대한 국내연구가 점차 진행되어 한국 아동의 일반적인 초기 발성 발달 패턴에 대한 자료가 나오고, 영어권 아동 과 비교해 한국 아동의 초기 발성에서 고유하게 관찰되는 점도 밝 혀지고 있다(Ha, 2017, 2018; Ha, Oller, \& Johnson, 2018; Ha, Seol, \& Pae, 2014; Kim \& Ha, 2013). 하지만 대부분의 연구가 9개월 이후 의 아동을 대상으로 진행되어 9 개월 이전의 초기 발성 발달에 대한 정보와 음절성 옹알이의 출현 시기 및 발달 과정을 살펴보기에는 부족하다. 또한 아동의 자연스런 환경에서 수집한 충분한 양의 발 성 자료를 토대로 살펴본 연구는 아직 없다. 그리고 국내연구는 호 흡 단위 또는 발성 간 2 초 이상의 침묵이 있는 경우 하나의 발화(utterance)로 분절한 것을 기본적인 발성의 분석 단위로 살펴보았기 때문에, 초기 발성에서의 음절성 옹알이의 비율을 제시하기에는 제한이 있었다. 따라서 음절성 옹알이가 보편적으로 출현한다고 보고되는 6개월 전-후의 한국 아동을 대상으로 일상 생활에서 아 동의 발성 빈도를 대표할 수 있는 충분한 발성 자료를 수집하여, 음 절을 기본 분석 단위로 한국 아동의 초기 발성 발달을 보다 포괄적 이고 정확하게 살펴볼 필요가 있다.

본 연구는 LENA를 이용하여 자연스런 아동의 언어환경에서 수 집된 자료를 토대로 생후 4-9개월 한국 아동의 초기 발성에 대해서 살펴보고자 하였다. 특히 초기 발성 발달 과정에서 가장 중요한 이 정표(milestone)라 할 수 있는 음절성 옹알이에 초점을 맞추어 살펴 보고자 하였다. 구체적으로 음절성 옹알이가 출현하는 것으로 보 편적으로 알려진 6개월을 기점으로 발달 현황을 살펴보기 위하여 아동을 4-6개월과 7-9개월로 월령 집단을 나누어 비교하였다. 또한 초기 말-언어 습득 수준이 성별에 따라서 달라질 수 있으므로(Bernthal, Bankson, \& Flipsen, 2013), 성별에 따라 초기 발성의 양과 발 달 수준이 달라질 수도 있다. 따라서 본 연구는 월령과 성별에 따라 서 음절성 옹알이의 비율이 어떠한지 살펴보고자 하였다.

\section{연구방법}

\section{대상자}

본 연구는 주양육자의 보고에 따라 출생 전-중-후와 발달상의 문제가 없었던 일반아동 26명(남 11명, 여 15명)을 대상으로 하였 다. 아동을 4-6개월 집단(남 5명, 여 8명, 평균연령 5.08개월)과 7-9 
개월 집단(남 6명, 여 7명, 평균연령 8.08개월)으로 나누었으며, 각 월령 집단을 13 명씩 구성하였다.

\section{자료 수집}

연구 절차는 한림대학교 생명윤리위원회의 승인(No. IRB-2016078-1-C)을 받아 진행되었다. LENA 녹음기(LENA Research Foundation, Boulder, CO, USA)를 이용하여 아동의 발성 자료를 수집하 였다. LENA 녹음기가 들어있는 조끼를 아침부터 밤에 잠들기 전까 지 하루 동안 가정에서 아동에게 착용시켰다. 아동당 12-14시간 연 속으로 녹음 자료가수집되었다.

\section{자료 분석}

자료 분석에는 언어병리학전공 대학원생 2 인과 언어치료사 1 인 이 참여하였다. 본 연구에서 발성 분석은 음절의 수와 유형에 대한 청지각적 판단에 의존하기 때문에 연구 시작 전에 체계적으로 분 석자 훈련을 실시하였다. 모든 분석자는 1 차적으로 두 저자로부터 20 시간 이상의 집중적인 듣기 및 분석 훈련을 받았다. 집중적인 훈 련 후 5 분짜리 음성파일 15 개(총 75 분 자료)를 독립적으로 분석하 게 한 뒤 각 측정치별로 분석자 간 신뢰도를 측정하여 신뢰도가 낮 은 분석치를 확인하고 추가적인 논의와 훈련을 반복적으로 실시하 였다. 이러한 분석작업을 3 번에 걸쳐 실시한 결과 모든 측정치에서
상관계수가. 80 이상을 보여 자료 분석을 본격적으로 시작하였다. 분석 자료를 선정하기 위해서 먼저 LENA 음성 자동 분석 소프 트웨어인 LENA pro (LENA Research Foundation)를 이용하여 아 동 개인별 전체 녹음자료에서 아동의 발화가 가장 빈번하게 나타나 는 구간을 확인하였다. 전체 자료에서 5 분 길이의 구간을 아동의 발 화수가 많은 순서로 20 개 선택하여, 아동당 100 분의 녹음 자료를 분석하였다. 월령을 포함해서 아동과 관련된 정보를 분석자에게 제공하지 않고 암맹 분석을 실시하였다.

아동 발성에 대한 청지각적 분석은 Action Analysis Coding and Training (AACT; Delgado, Buder, \& Oller, 2010) 프로그램을 이용 하였다. AACT는 아동의 초기 발성을 위해 Oller 연구진에 의해 개 발된 프로그램으로, 분석자가 음성자료를 들으면서 미리 지정해 둔 측정치 유형에 해당하는 컴퓨터 자판을 눌러 측정치 값을 입력하 여 실시간으로 음성자료를 분석할 수 있다. 또한 음성자료를 들으 면서 해당 음원의 파형과 스펙트로그램을 실시간으로 동시에 볼 수 있어 청지각적 판단을 할 때 음향학적 특성을 보완적으로 참고 할 수 있다. Figure 1은 AACT를 이용하여 초기 발성을 분석한 예 로서 음원의 파형 및 스펙트로그램과 분석 입력창이 제시되었다.

AACT를 이용한 음절성 옹알이 분석 방법과 기준은 Lee 등(2018) 을 참조하였다. 울음, 웃음, 재채기, 딸꾹질 소리와 같은 생리적인 소 리는 분석에서 제외하였으며, 음절을 기본 분석 단위로 정하였다.

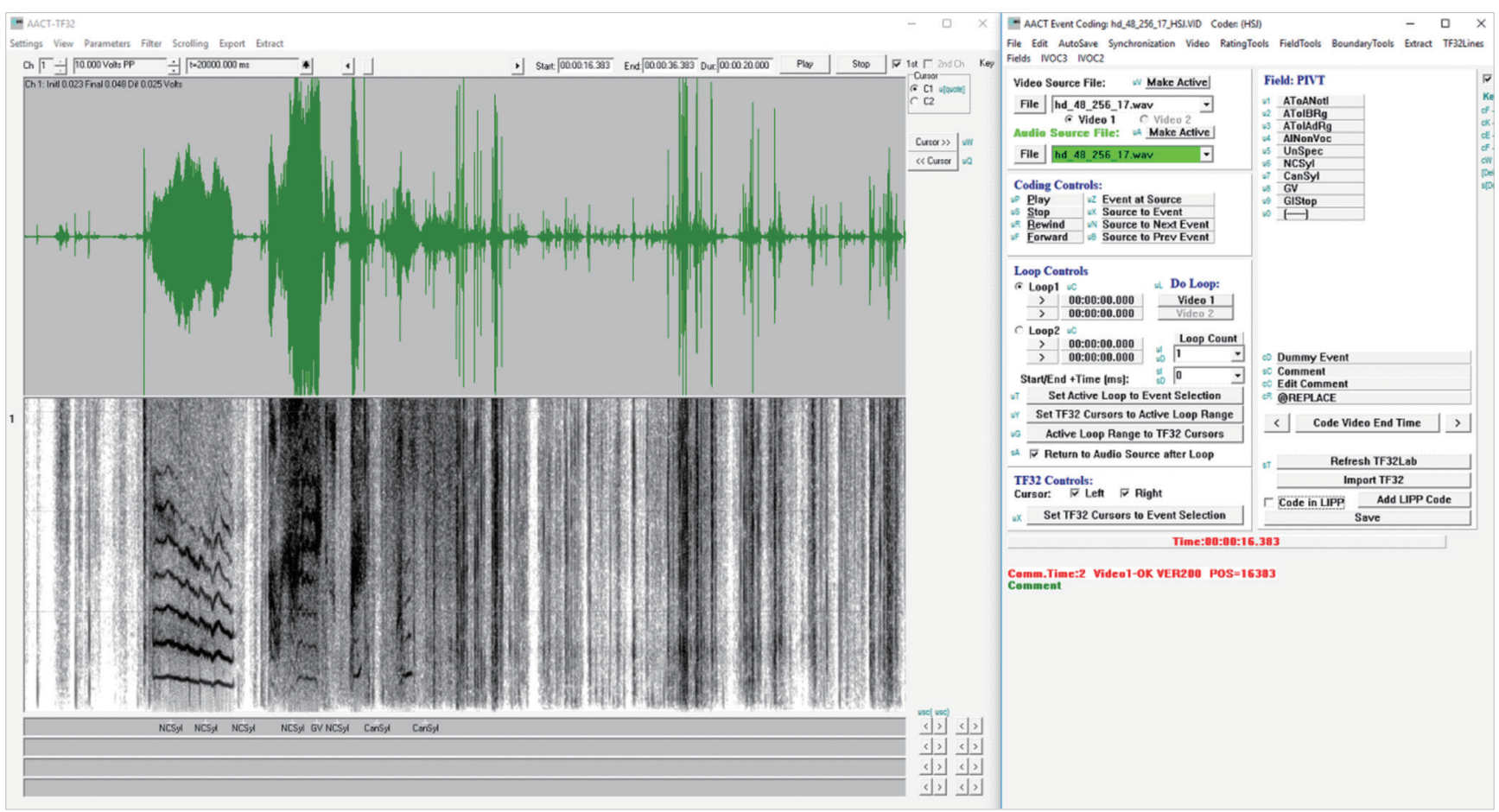

Figure 1. Example of analysis window using the Action Analysis Coding and Training program. 
본 연구에서의 음절은 모음핵을 포함한 일반적인 성인의 음절 구 조를 지칭하기보다는 한 호흡으로 산출되는 발화의 최소 리듬 단 위이며, 발성에서 지각되는 비트(beat)에 해당한다. 모든 분석자는 발성의 리듬에서 지각되는 비트를 토대로 음절의 수를 셀 수 있게 훈련받았다. 발성의 모든 음절을 (1) 적어도 하나의 자음과 모음으 로 구성된 음절성 옹알이와, (2) 자음-모음 구조가 포함되지 않은 비음절성 옹알이(non-canonical babbling), (3) 활음을 포함한 옹알 이, (4) 성문파열음을 포함한 옹알이로 총 4가지 유형으로 나누어 살펴보았다. 기본 음절(canonical syllable)을 포함하는 음절성 옹알 이는 Oller (2000)의 정의대로 성대 진동과 함께 턱, 입술 또는 혀의 움직임으로 만들어지는 리드미컬한 정형화된 소리로서 (1) 완전 공 명핵, (2) 자음 같은 소리를 만들어내는 상후두 조음기제(혀, 입술, 턱)의 움직임, 그리고 (3) 공명핵과 자음 같은 소리 사이의 짧은 포 먼트 전이구간을 반드시 포함해야 한다. 활음은 우리말에서는 자 음으로 분류되지는 않지만 상후두 조음기제(혀, 입술, 턱)의 움직임 이 동반되어 자음에 보다 가까운 조음 및 음성 특성을 보이기 때문 에 활음 $[\mathrm{j}, \mathrm{w}]$ 가 포함된 음절의 경우는 따로 분류하여 살펴보았다. $\mathrm{AACT}$ 프로그램에 4 가지 유형에 해당하는 자판을 미리 지정하여 분석자가 녹음 자료를 들으면서 동시에 해당 자판을 음절수만큼 누르게 하였다. 음절성 옹알이 비율(canonical babbling ratio)은 자

Table 1. The number of syllables in vocalization

\begin{tabular}{ccccccc}
\hline & \multicolumn{2}{c}{$4-6$ mo group } & & \multicolumn{2}{c}{$7-9$ mo group } \\
\cline { 2 - 3 } \cline { 5 - 6 } & Boy $(\mathrm{N}=5)$ & $\operatorname{Girl}(\mathrm{N}=8)$ & & Boy $(\mathrm{N}=6)$ & Girl $(\mathrm{N}=7)$ \\
\hline Number of syllables & $1,221(1,163.00)$ & $805(1,396)$ & & $1,318(1,396)$ & $864(1,382)$ \\
\hline
\end{tabular}

Values are presented as median (range).
음과 활음이 포함된 음절의 비율로서 음절성 옹알이와 활음을 포 함한 옹알이의 음절수를 전체 음절수로 나누어 구하였다(Lynch, et al., 1995; Oller et al., 1994).

\section{통계 분석}

통계 처리는 SPSS 22.0 프로그램을 사용하였다. 표본의 수에 따 른 정규분포 검정을 실시한 결과, 일부 측정치에서 정규분포가 나 타나지 않았다. 따라서 비모수 검정인 Mann-Whitney $U$-test를 월 령 집단 및 성별에 따라 실시하였으며, 대표값으로 중앙값과 범위 를 살펴보았다. 모든 유의 수준은 $p<.05$ 로 설정하였다.

\section{연구결과}

\section{총 음절수}

아동당 총 100 분의 분석 자료에서 관찰된 총 음절수를 Table 1 에 제시하였다. 통계 분석 결과, 월령 집단에 따라 총음절수는 유의미 한 차이를 보이지 않았다. 또한 성별에 따라서도 총 음절수는 유의 미한차이를 보이지 않았다.

Table 2. The number of each type of syllables in vocalization

\begin{tabular}{lcccccc}
\hline & \multicolumn{2}{c}{$4-6$ mo group } & & \multicolumn{2}{c}{$7-9$ mo group } \\
\cline { 2 - 3 } \cline { 5 - 6 } & Boy & Girl & & Boy & Girl \\
\hline Canonical syllables & $65(104)$ & $16(29)$ & & $178(698)$ & $169(329)$ \\
Non-canonical syllables & $962(896)$ & $685(983)$ & & $1,022(574)$ & $707(1,016)$ \\
Glides & $4(73)$ & $1.5(33)$ & & $16(83)$ & $15(28)$ \\
Glottal stops & $101(164)$ & $75.5(378)$ & & $32(165)$ & $70(119)$ \\
\hline
\end{tabular}

Values are presented as median (range).

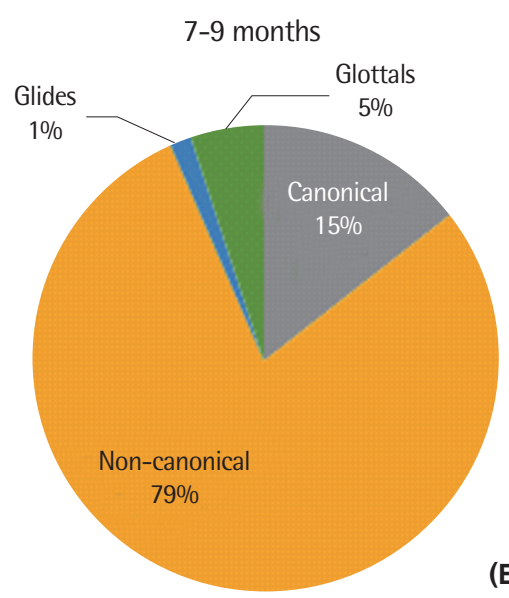

Figure 2. The percentage of each type of syllables in the two age groups: (A) 4-6 months group and (B) 7-9 months group. 


\section{음절 유형별 수와 비율}

아동이 산출한 음절을 (1) 적어도 하나의 자음과 모음으로 구성 된 음절성 옹알이와, (2) 자음-모음을 포함하지 않는 비음절성 옹알 이(non-canonical babbling), (3) 활음을 포함한 옹알이, (4) 성문파 열음을 포함한 옹알이로 총 4 가지 유형으로 나누어 살펴본 결과는 Table 2 와 같다. 또한 각 유형별 음절수가 전체 음절수에서 차지하 는 비율을 두 월령 집단별로 Figure 2에 제시하였다. 두 월령 집단 모두 비음절성 옹알이 산출이 가장 높았다. 음절성 옹알이는 월령 이 증가함에 따라 증가하였으며 성문파열음이 포함된 옹알이는 감 소하였다. 음절성 옹알이는 4-6개월에는 전체 음절에서 평균 $4 \%$ 정 도에 해당하였는데 7-9개월에는 평균 $15 \%$ 정도로 증가하였다.

4 가지 음절 유형 중 음절성 옹알이만이 월령 집단에 따라 통계적 으로 유의한차이를 보였다 $(U=36.00, p=.013)$. 성별에 따라서도 음 절성 옹알이만이 유의한 차이를 보여 $(U=40.00, p=.027)$, 남아가

Table 3. Canonical babbling ratio (CBR)

\begin{tabular}{|c|c|c|c|c|}
\hline & Child no. & Age (mo) & Gender & CBR \\
\hline \multirow[t]{13}{*}{ 4-6 mo group } & 1 & 4 & Boy & .066 \\
\hline & 2 & 4 & Boy & .039 \\
\hline & 3 & 5 & Boy & .088 \\
\hline & 4 & 5 & Boy & .085 \\
\hline & 5 & 5 & Boy & .129 \\
\hline & 6 & 4 & Girl & .027 \\
\hline & 7 & 5 & Girl & .056 \\
\hline & 8 & 5 & Girl & .023 \\
\hline & 9 & 5 & Girl & .011 \\
\hline & 10 & 6 & Girl & .031 \\
\hline & 11 & 6 & Girl & .018 \\
\hline & 12 & 6 & Girl & .030 \\
\hline & 13 & 6 & Girl & .012 \\
\hline \multirow[t]{13}{*}{$7-9$ mo group } & 14 & 7 & Boy & $.174^{\mathrm{a}}$ \\
\hline & 15 & 8 & Boy & $.378^{\mathrm{a}}$ \\
\hline & 16 & 9 & Boy & .033 \\
\hline & 17 & 9 & Boy & .080 \\
\hline & 18 & 9 & Boy & $.376^{a}$ \\
\hline & 19 & 9 & Boy & $.159^{a}$ \\
\hline & 20 & 7 & Girl & .001 \\
\hline & 21 & 7 & Girl & $.155^{\mathrm{a}}$ \\
\hline & 22 & 7 & Girl & $.186^{a}$ \\
\hline & 23 & 8 & Girl & .042 \\
\hline & 24 & 8 & Girl & $.210^{\mathrm{a}}$ \\
\hline & 25 & 8 & Girl & .088 \\
\hline & 26 & 9 & Girl & $.227^{\mathrm{a}}$ \\
\hline
\end{tabular}

In 4-6 mo group, mean=0.047, median=0.031, range=0.118; in 7-9 mo group, mean $=0.162$, median $=0.159$, range $=0.376$.

alndicates a child who achieved the canonical babbling stage.
여아보다 유의하게 음절성 옹알이의 수가 높은 것으로 나타났다.

\section{음절성 옹알이 비율}

아동 개인별로 자음과 활음이 포함된 음절이 전체 음절에서 차 지하는 비율에 해당하는 음절성 옹알이 비율을 구하였다(Table 3). 4-6개월과 7-9개월 두 월령 집단의 평균 음절성 옹알이 비율은 각 각 .047과. 162 로 나타났다. 음절성 옹알이에 관한 선행연구(Lynch et al., 1995; Oller et al., 1994)에서 제시된 .15의 기준을 토대로 결과 를 살펴보면 7-9개월 집단의 13 명 중 총 8 명이 음절성 옹알이 단계 에 진입한 것으로 나타났다. 반면에 4-6개월 집단에서는 모든 아동 이 음절성 옹알이 비율이 .15 이하로 나타났다. 아동별 수행력을 자 세히 살펴보면 4-6개월은 음절성 옹알이 비율의 범위가 .118로 비 교적 개인차가 적은 반면에 7-9개월은 그 범위가 .376로 아동 개인 간 상당히 큰 차이를 보였다. 특히 아동 20 은 7 개월이지만 전체 711 개의 음절 중 1 개만이 음절성 옹알이로 분석되어 음절성 옹알이 비 율이 .001로 나타나 발성 발달이 느린 것으로 나타났다.

Mann-Whitney $U$-test로 검증한 결과, 음절성 옹알이 비율은 월 령 $(U=29.00, p=.004)$ 과 성별 $(U=43.00, p=.040)$ 에 따라 각각 유 의한차이를 보였다.

\section{논의 및 결론}

본 연구는 LENA를 이용하여 자연스런 아동의 언어환경에서 12 시간 이상 수집된 자료를 토대로 생후 4-9개월 한국 아동의 음절성 옹알이 발달 현황에 대해서 살펴보고자 하였다. 구체적으로 음절 성 옹알이가 출현하기 시작한다고 보고되는 6 개월을 기점으로 발 달 현황을 살펴보기 위하여 아동을 4-6개월과 7-9개월로 월령 집 단을 나누었으며, 월령과 성별에 따라서 음절성 옹알이의 비율이 어떠한지 살펴보고자 하였다.

먼저 아동당 총 100 분의 분석 자료에서 관찰된 총 음절수는 월령 집단과 성별에 따라 유의미한 차이를 보이지 않았다. 아동이 산출 한 음절을 4 가지 유형으로 나누어 살펴본 결과, 두 월령 집단 모두 비음절성 옹알이 산출이 가장 높았다. 월령이 증가함에 따라 음절 성 옹알이의 수는 증가하였으며 성문파열음이 포함된 옹알이 수는 감소하였다. 월령 집단 및 성별에 따라 차이를 나타내는지 살펴본 결과, 4 가지 음절 유형 중 음절성 옹알이만 월령 집단에 따라 유의 한 차이를 보였다. 또한 아동 개인별로 전체 음절에서 자음과 활음 이 포함된 음절이 차지하는 비율인 음절성 옹알이 비율을 구한 결 과도 월령 집단에 따라 유의한 차이를 보였다. 총 음절수 결과와 함 께 음절 유형별 결과를 종합해 보면 생후 4-9개월 동안에는 발성의 
양보다는 질 또는 구조상의 변화가 일어난다고 할 수 있다. 즉 성대 진동과 조음기관의 운동 속도가 점차 빨라져 자음과 모음의 소리가 명확해지고 자음-모음 간 전이구간이 짧아지면서 음절성 옹알이가 출현하는 것이 이 시기의 발성 발달에 있어서 주요한 특징이다.

성별에 따른 음절성 옹알이를 살펴본 결과, 음절성 옹알이의 수 와 비율이 여아에 비해 남아가 유의하게 높게 나왔다. 이러한 결과 는 음절성 옹알이의 수가 10 개 미만으로 아주 적은 수로 산출한 아 동이 전체 아동 중 4 명이 있었는데 모두 여아인 점과 관련이 있다. 따라서 추후 한국 아동을 대표할 수 있는 보다 많은 수의 아동들 을 대상으로 연구를 진행하여 성별에 따른 본 연구의 결과를 일반 화할 수 있는 것인지 다시 검증할 필요가 있다. 또한 본 연구에서 6-8개월에 적은 수의 음절성 옹알이를 산출한 아동이 언어기에는 어떠한 발달을 보이는지 추적 조사한다면 음절성 옹알이가 이후 말-언어발달과 얼마나 상관이 있는지 살펴볼 수 있을 것이다.

음절성 옹알이에 관한 선행연구(Lynch et al., 1995; Oller et al., 1994)에서 제시된 .15의 기준을 토대로 음절성 옹알이 단계에 진입 한 아동 현황을 살펴보았다. 4-6개월 집단에서는 모든 아동이 음절 성 옹알이 비율이 .15 이하로 나타난 반면에 7-9개월 집단에서는 13 명 중 총 8 명이 음절성 옹알이 단계에 진입한 것으로 나타났다. 그리 고 4-6개월과 7-9개월 두 월령 집단의 평균 음절성 옹알이 비율은 각각.047과.162로 나타났다. 본 연구와 비슷한 방법으로 자료 수집 과 분석을 실시하여 6 개월과 11 개월 시점에 중국어권과 영어권 아 동의 음절성 옹알이 비율을 살펴본 Lee 등(2018)에서는 중국어권 6 개월과 11 개월 아동의 경우 각각 평균 음절성 옹알이 비율이 .06과 .11 로 나타났다. 영어권 6 개월과 11 개월 아동의 경우 평균 음절성 옹알이 비율이 각각 .03과 .11로 나타났다. 본 연구에서는 생후 6개 월을 기점으로 4-6개월과 7-9개월로 아동을 나누어 살펴보았기 때 문에 선행연구 결과와 직접적으로 비교할 수는 없지만, 4-6개월의 평균 음절성 옹알이 비율은 중국어권과 영어권 6개월 아동과 비슷 한 수치로 나타났다. 7-9개월 한국 아동은 선행연구의 11 개월 중국 어, 영어권 아동보다 평균 음절성 옹알이 비율이 높게 나타났다. Lee 등(2018)은 연구에 앞서 중국어가 영어에 비해 음절구조가 상 대적으로 단순하기 때문에 생후 6 개월과 11 개월 중국어권 아동이 영어권 아동보다 음절성 옹알이의 비율이 더 높을 것으로 가정하 였다. 연구결과, 연구자의 가정대로 음절성 옹알이 비율이 언어에 따라 유의미한 차이를 보이지는 않았다. 하지만 아동의 월령뿐만 아니라 언어 및 문화 환경, 상호작용 환경이 복합적으로 음절성 옹 알이 산출에 영향을 주는 것으로 나타났다. 선행연구의 이러한 결 과는 언어이전기 발성은 언어의 보편적인 특성뿐만 아니라 아동에 게 노출된 언어에 국한된 고유한 특성이 나타날 수 있고, 아동을 양
육하는 문화와 상호작용 방식에 따라 복합적으로 달라질 수 있음 을 제안하고 있다. 비록 Lee 등(2018)의 연구에서는 언어 간 음절성 옹알이 비율에 대한 가정은 분명하게 증명되지 않았지만 본 연구에 서 7-9개월 한국 아동이 보인 상대적으로 높은 음절성 옹알이 비율 은 한국어의 비교적 단순한 음절구조와 관련이 있을 수 있다.

$\mathrm{Ha}$ 등(2018)은 9-21개월 미국 아동과 한국 아동의 초기 발성의 양과 구조를 비교하였다. 분석 결과 두 언어권 아동은 전체 발성의 양과음절성 옹알이의 비율 면에서는 유의미한 차이를 보이지 않았 으나 음절성 옹알이의 구조에서는 차이를 보였다. 음절성 옹알이에 서 미국 아동은 $\mathrm{CV}$ 구조가 가장 우세하였으나, 한국 아동은 $\mathrm{VCV}$ 구조가 가장 우세하여 발성의 VCV 구조비율이 유의미하게 높은 것으로 나타났다. 연구자들은 한국 아동이 우세하게 산출하는 $\mathrm{VCV}$ 의 발성 구조는 '엄마, 아빠'와 같은 초기 어휘와 깊은 관계가 있다고 해석하였다. 즉 아동이 음절성 옹알이를 산출하기 시작할 때 초기 어휘와 비슷하게 들리는 발성의 경우 양육자가 긍정적인 반응을 보이고 강화하여 점차 산출의 빈도도 증가하고 의미 있는 낱말로 발달해 나가는 것과 관련이 있다. 연구대상자의 연령이 달 라 직접적인 비교는 제한적이지만 본 연구와 동일한 방식으로 아동 의 발성을 수집하고 분석한 Lee 등(2018)과 Ha 등(2018)의 연구를 종합해 보면 한국 아동이 7-9개월에는 음절성 옹알이의 비율이 상 대적으로 높다가 9 개월 이후에는 영어권 아동과 비슷한 수준으로 산출되고 양보다는 초기 어휘에 영향을 받아 옹알이의 구조에서 차이가 두드러진다고 할 수 있다. 이러한 해석의 타당성은 추후 더 넓은 월령대의 아동들을 포함하는 연구를 통해 객관적으로 점검 해야 할 것이다.

본 연구는 아동의 자연스런 가정 환경에서 수집된 충분한 양의 발성 자료를 토대로 생후 9개월 이전의 한국 아동의 발성 발달 수 준을 살펴본 첫 번째 시도라고 할 수 있다. 12 시간 이상 연속해서 녹음한 자료에서 아동의 발성 비율이 높은 100 분의 자료를 추출하 여 발성의 음절 유형을 분석하였기 때문에 아동의 발달 수준을 대 표하는 자료를 토대로 아동 개인별 발성 발달 현황을 살펴보았다 는 장점이 있다. 하지만 월령별로 비교적 적은 수의 아동을 대상으 로 음절성 옹알이에 주로 초점을 맞추어 진행되었기 때문에 초기 발성 발달 과정에 대한 일반적인 결과를 제시하기에는 제한이 있 다. 따라서 추후에는 월령별로 보다 많은 수의 아동을 대상으로 음 절성 옹알이뿐만 아니라 다양한 원시 발성(protophone)을 포함하 여 한국 아동의 초기 발성 발달 과정을 보다 포괄적이고 타당하게 살펴봐야 할 것이다. 이러한 후속 연구는 영어권 아동의 초기 발성 에 근거한 평가 모형이 아닌 한국 아동의 발성 자료에 근거한 자료 를 토대로 한국어를 습득하는 아동을 타당하게 평가할 수 있는 계 
기를 마련할 것이다. 또한 종단 추적조사를 통해 초기 발성과 이후 말-언어발달의 관계가 어떠한지 살펴봐야 한다. 특히 음절성 옹알 이의 출현 시기와 이후 말-언어발달의 상관관계가 높다는 선행연 구(Chapman et al., 2003; Cobo-Lewis et al., 1996; Ertmer et al., 2007; Iyer \& Ertmer, 2014; Nathani et al., 2006; Oller et al., 1985) 결과를 고려한다면 지속적인 연구를 통해 아동의 말-언어발달 지 연과 문제를 정확하게 예측할 수 있는 초기 발성 특징을 구체적으 로 제시할 필요가 있다. 이러한 노력은 궁극적으로 언어이전기 초 기 발성을 토대로 말-언어문제를 타당하고 정확하게 예측할 수 있 게 하며, 객관적인 준거에 기반하여 조기언어중재가 필요한 아동을 선별하고 치료를 제공하는 데 기여할 것이다.

\section{REFERENCES}

Bernthal, J. E., Bankson, N. W., \& Flipsen, P. (2013). Articulation and phonological disorders: speech sound disorders in children (7th ed.). Boston, MA: Pearson.

Chapman, K. L., Hardin-Jones, M., \& Halter, K. A. (2003). The relationship between early speech and later speech and language performance for children with cleft lip and palate. Clinical Linguistics \& Phonetics, 17(3), 173-197.

Chapman, K. L., Hardin-Jones, M., Schulte, J., \& Halter, K. A. (2001). Vocal development of 9-month-old babies with cleft palate. Journal of Speech, Language, and Hearing Research, 44(6), 1268-1283.

Cobo-Lewis, A. B., Oller, D. K., Lynch, M. P., \& Levine, S. L. (1996). Relations of motor and vocal milestones in typically developing infants and infants with Down syndrome. American Journal of Mental Retardation, 100(5), 456-467.

Delgado, R. E., Buder, E. H., \& Oller, D. K. (2010). Action analysis coding and training (AACT). Miami, FL: Intelligent Hearing Systems.

Ertmer, D. J., Young, N. M., \& Nathani, S. (2007). Profiles of vocal development in young cochlear implant recipients. Journal of Speech, Language, and Hearing Research, 50(2), 393-407.

Gilkerson, J., Richards, J. A., Warren, S. F., Montgomery, J. K., Greenwood, C. R., Oller, D. K., ... \& Paul, T. D. (2017). Mapping the early language environment using all-day recordings and automated analysis. American Journal of Speech-Language Pathology, 26(2), 248-265.

Ha, S. (2017). Longitudinal study of vocal development in 9-to 18-monthold children acquiring Korean. Communication Sciences \& Disorders, 22(3), 435-444.

Ha, S. (2018). Profiles of vocal development in Korean children with and with- out cleft palate. Clinical Linguistics \& Phonetics, 32(1), 46-69.

Ha, S., Oller, K., \& Johnson, C. (2018). Cross-linguistic comparisons of babbling shapes in Korean- and English-learning infants. Proceedings of the International Child Phonology Conference, Crete, Greece.

Ha, S., Seol, A., \& Pae, S. (2014). Vocal development of typically developing infants. Phonetics and Speech Sciences, 6(4), 161-169.

Iyer, S. N., \& Ertmer, D. J. (2014). Relationships between vocalization forms and functions in infancy: preliminary implications for early communicative assessment and intervention. American Journal of Speech-Language Pathology, 23(4), 587-598.

Kim, M., \& Ha, S. (2013). Longitudinal study of early vocalization development in toddlers with and without cleft palate from 6 to 18 months of age. Communication Sciences \& Disorders, 18(2), 223-234.

Lee, C. C., Jhang, Y., Relyea, G., Chen, L. M., \& Oller, D. K. (2018). Babbling development as seen in canonical babbling ratios: a naturalistic evaluation of all-day recordings. Infant Behavior and Development, 50, 140-153.

Lynch, M. P., Oller, D. K., Steffens, M. L., Levine, S. L., Basinger, D. L., \& Umbel, V. (1995). Onset of speech-like vocalizations in infants with Down syndrome. American Journal on Mental Retardation, 100(1), 68-86.

Nathani, S., Ertmer, D. J., \& Stark, R. E. (2006). Assessing vocal development in infants and toddlers. Clinical Linguistics \& Phonetics, 20(5), 351-369.

Oller, D. K. (2000). The emergence of the speech capacity. Mahwah, NJ: Lawrence Erlbaum Associates.

Oller, D. K., Eilers, R. E., Bull, D. H., \& Carney, A. E. (1985). Prespeech vocalizations of a deaf infant: a comparison with normal metaphonological development. Journal of Speech, Language, and Hearing Research, 28(1), 4763.

Oller, D. K., Eilers, R. E., Steffens, M. L., Lynch, M. P., \& Urbano, R. (1994). Speech-like vocalizations in infancy: an evaluation of potential risk factors. Journal of Child Language, 21(1), 33-58.

Oller, D. K., Levine, S. L., Cobo-Lewis, A. B., Eilers, R. E., \& Pearson, B. Z. (1998). Vocal precursors to linguistic communication: how babbling is connected to meaningful speech. In R. Paul (Ed.), Exploring the speechlanguage connection (pp. 1-23). Baltimore, MD: Paul H. Brookes Publishing.

Oller, D. K., Niyogi, P., Gray, S., Richards, J. A., Gilkerson, J., Xu, D., ... \& Warren, S. F. (2010). Automated vocal analysis of naturalistic recordings from children with autism, language delay, and typical development. Proceedings of the National Academy of Sciences, 107(30), 13354-13359. 


\section{국문초록}

\section{4-9개월 한국 아동의 음절성 옹알이}

\section{하승희 ${ }^{1} \cdot \mathrm{D}$. Kimbrough Oller $^{2}$}

1한림대학교 언어청각학부, 한림청각언어연구소, ${ }^{2}$ University of Memphis

배경 및 목적: 음절성 옹알이의 출현은 생후 1년 동안 점진적으로 습득해가는 말산출 능력에 있어서 가장 중요한 발달을 의미한다. 본 연구는 아동의 자연스런 가정 환경에서 하루 동안 수집된 발성 자료를 토대로 4-9개월 한국 아동의 음절성 옹알이의 발달을 자세히 살 펴보고자 하였다. 방법: 주양육자의 보고에 따라 출생 전-중-후와 발달상의 문제가 없었던 생후 4-9개월 된 26명의 일반아동이 연구에 참여하였다. 언어환경분석기(Language ENvironment Analysis, LENA)를 이용하여 아동의 가정에서 하루 동안 녹음자료를 수집하였 다. LENA 녹음 자료에서 아동의 발성 수가 많은 순서로 5 분 길이의 구간을 20 개 선택하여, 아동당 100 분의 녹음 자료를 분석하였다. 초 기 발성에 대한 집중적인 훈련을 마친 분석자가 선택된 녹음 자료를 들으면서 발성의 4 가지 음절 유형(음절성, 비음절성, 활음, 성문파열 음이 포함된 음절)을 정하였다. 아동을 4-6개월과 7-9개월의 월령 집단으로 나누어 월령과 성별에 따라 각 발성 음절의 수와 음절성 옹 알이의 비율이 유의미하게 다른지 살펴보았다. 결과: 7-9개월 집단은 4-6개월 집단보다 음절 유형 중 음절성 옹알이의 수가 유의미하게 많아 음절성 옹알이 비율이 높았다. 7-9개월 월령 집단에서 8명이 음절성 옹알이 단계에 진입한 것으로 나타났다. 본 연구에서는 음절 성 옹알이의 수와 음절성 옹알이 비율은 성별에 따라 유의미한 차이를 보였다. 논의 및 결론: 본 연구는 자연스런 가정 환경에서 아동 의 발성을 대표할 수 있는 충분한 녹음 자료를 토대로 6 개월 미만의 어린 한국 아동을 대상으로 음절성 옹알이의 발달상의 변화를 자세 히 제시하였다.

핵심어: 음절성 옹알이, 언어환경분석기, 4-9개월, 한국 아동

본 논문은 한국연구재단 글로벌연구네트워크사업(No. NRF-2016S1A2A2911363)과 한림대학교 교비 학술연구과제(No. HRF-201812-013) 에 의해수행되었음.

\section{참고문헌}

김민영, 하승희(2013). 6-18개월 구개열 영유아와 일반 영유아의 발성 발달에 관한 종단연구. Communication Sciences \& Disorders, 18(2), 223-234. 하승희(2017). 9-18개월 일반 한국 아동의 초기 발성에 대한 종단 연구. Communication Sciences \& Disorders, 22(3), 435-444. 하승희, 설아영, 배소영(2014). 일반 영유아의 초기 발성 발달 연구. 말소리와음성과학, 6(4), 161-169.

\section{ORCID}

하승희(https://orcid.org/0000-0003-2133-3720); D. Kimbrough Oller (https://orcid.org/0000-0001-5527-5982) 